\title{
Preface to the American Edition
}

Distance and closeness between people in their social space is a central concern of cultural sciences. Arthur Schopenhauer formulated the necessity of solving this problem in his famous parable of the freezing porcupines. On a cold winter's day an assortment of porcupines needs to set an adequate distance among its members. Being too close, they risk mutual injury from their quills; being too far apart, they are bound to die of exposure. The porcupines, as Schopenhauer writes, are torn between closeness and distance until they settle on a moderate temperature at which they can tolerate their situation.

This book is about "adequate distance," which is a construct of cultural history. The historical setting is Germany from I9I4 to I945, the time of a thirty years' war. The book depicts the traumatic situation after the capitulation of I9I8. The familiar horizons of the Wilhelmian empire are gone. After the loss of the authoritative system, people experience the immediate confrontation with modernity as a freezing shock. In counterreaction, the ideal of a glowing community displaces the coldness of industrialized civil society.

In this situation of a cult of community with its fatal political consequences, the philosophical anthropologist Helmuth Plessner intervenes with a manifesto on cool conduct, Grenzen der Gemeinschaft: Eine Kritik des sozialen Radikalismus (The boundaries of community: a critique of social radicalism). It is a document of a culture of distance, rare and precious because German cultural history never appreciated it. 
Plessner escapes from the intelligentsia's traditional views on civilization to discover the open horizon of possibilities in the anonymity of public existence. Grenzen is also an early manifesto against the "tyranny of intimacy," as Richard Sennett labels it five decades later. In I924 Plessner states: "As a guiding principle, authenticity is not right for strangers. ... After a sudden collision, the coldness of outer space must sink between them."

Plessner's manifesto interests us today because of its uncanny relevance to the problems that have arisen in the debate on communitarianism. In a harsh polemic against the cult of Gemeinschaft (community), Plessner stresses the dark side of the communitarian ideology. He respects the longing for community, inasmuch as it is a wish to avoid separation from others. However, his critique addresses the shortcomings of that concept. The German ideology of community obscures violence and hatred inside a community; it overlooks the necessity of, and the right for, spheres of mistrust. It forgets that it is only a part of the social framework, that its critique of liberal society benefits from the latter's basic principles. And, finally, its fundamentalism strips away the boundaries of the individual's body, destroys his personal space; its cult of authenticity and the reign of terror are kindred spirits.

Plessner contrasts the identikit picture of community as a symbiotic companionship with an idea of society that lacks idyllic features. It is an open system of unencumbered strangers. Abstract juridical norms regulate its sphere, in which human beings appear only as persons. In order to function according to its laws, they must forget their primal embedding in community, distance themselves from those spheres of trust "in which we still kept ourselves warm." An absence of values, rather than shared moral ideas, marks its public space. It comprises the spheres of education, of state and economy. The subspheres' moral values must not influence the public sphere:

In every sphere of human interactions, the idea of realizable order must take precedence over the law of pure values. That is because what dims and refracts the pure light of values is the complete disjunction in human existence between familiarity and objectivity.

The public sphere consists of equal, disconnected persons, "not because they are equal to, but because they are equal for each other." Plessner knows that individuals must use force to free themselves from their familiar space of trust, and that life in the "coldness of society" involves a permanent balancing act. 
Leading a life in alienation is an art. To do so, people have to develop rules of a social game that will allow them to "get close without violating each other, and to separate without injury." Social rites bring relief to this balancing act: ceremony, diplomacy, and tact. Supplied with these, individuals can achieve elegance and power. In these reflections Plessner touches problems that will resurface fifty years later in the debate on communitarianism. But Plessner believes he solved the problems, in a single stroke, by constructing an anthropology of the social person.

From a communitarian viewpoint, the concept of liberalism as represented in John Rawls's Theory of Justice starts at the point where membership in society outranks membership in community. It obliges individuals to let go of familiar moral values in community to prove themselves as juridical persons in society. Communitarians attacked Rawls's "unencumbered self" as a figure of coldness. Ralf Dahrendorf called liberalism itself a "cold project."

Indeed the concept raises broad questions about violent abstraction from community existence, questions that Rawls was unable to answer:

On which passions, hunger, longings, eros is the necessary separation from familiar bondage to be based? Which interest can form the reason for the art of separation?

How violent must the force to abstraction be in order to make a community being a juridical person? How can this force be institutionalized? Can institutionalized power find a mooring in the human psyche?

As he addresses these problems, Plessner does not follow Thomas Hobbes's plan to impel human beings to submit to social norms. Instead, Plessner assumes that individuals develop their inner nature to the full in a violence-based public life. That is because-as his paradox says- "man is artificial by nature." The violence-based artificiality of civilization is the genuine medium of life! The leading principles of this anthropology are succinct: at birth, man is in an "eccentric" relation to his environment. He needs the artificiality of a second nature, a cultural context that he weaves around him in order to survive. Man is naturally a cultural being; he has to conduct his life.

"Artificiality in action, thought, and dreams is the inner means by which man comes to terms with himself as a natural being." All expression of his psyche is subject to the fluctuations of the laws of symbolic order. This stroke of genius is to offset a shortcoming of German cul- 
tural history. But there are traces of the project's violence in several formulations of Plessner's work.

The present book examines the curious dimensions of the anthropological principle, "man is artificial by nature." It reconstructs the principle's historical background, as well in its involvement in Nietzschean aestheticism as in its affinity to the pronouncements of the European avant-garde. The study questions how a brief alliance of this thought with that of the legal theorist Carl Schmitt could have come about. Schmitt found an anthropological basis for his political friend-enemy formula in Plessner's texts of the I920s. For his part, Plessner referred to Schmitt in political questions. One of them became the crown jurist of the Third Reich, the other took refuge in the Netherlands as an exile. The codes of cool conduct form a hidden intersection of the various political camps in pre-Hitler Germany. Underneath the political differences fantastic alliances developed: all of a sudden we glimpse a subterranean link between Ernst Jünger and Bertolt Brecht, Walter Benjamin in correspondence with Carl Schmitt, Werner Krauss, a resistance fighter, in touch with the dadaist Walter Serner.

All these unlikely neighbors venerated-and here is the secret center of this book-a conduct code of the seventeenth century: the Art of Worldly Wisdom, written in 1647 by the Spanish Jesuit Balthasar Gracián.

Cool Conduct in fact tries some sort of "border-surfing" to find out whether this phase of Germany's classic modernity had a shared radical core beyond the political rhetoric. Having defined this core in all its strangeness, we can more easily dismiss a catastrophic epoch that held us spellbound for so long.

Rostock, 22 May 1998

Preface translated by Caroline Sommerfeld 